\title{
Consortial Usage of Electronic Journals in Turkey
}

\section{Bülent Karasözen}

\author{
Former ANKOS chairman, Middle East Technical University, Department \\ of Mathematics \& Institute of Applied Mathematics, 06531 Ankara, Turkey, \\ bulent@metu.edu.tr
}

\begin{abstract}
In this short article the increase in the usage of electronically licensed databases by ANKOS (Anatolian University Libraries Consortium) is explained with reference to COUNTER compliant e-journal collections. The diversity of usage among the universities and the cost-effectiveness of electronically available databases with the consortium is explained, taking into account the special characteristics of Turkish university libraries, the rapid increase of students and newly established universities, as well as the growth of scientific publications.
\end{abstract}

Key Words: consortia; big deals; COUNTER; usage; e-journals

\section{Introduction}

The usage of electronic journals in Turkish universities and research institutions has increased geometrically since the establishment of $\underline{\text { ANKOS }}$ (Anatolian University Libraries Consortium) in 2001. ANKOS started in 2001 with only a few members having access to nine e-journal collections and bibliographic databases. Over time, the number of licensed databases within the big deal negotiations with published and participating members of the consortium increased rapidly. In 2007, 86 member institutions were accessing 40 electronic journal packages, e-references, bibliographic databases and e-book collections of commercial and society publishers. The success of ANKOS is similar to other consortia around the world. The motivation for the increased usage of electronically available scientific information was influenced in 
Turkey by the following factors: the universities' insufficient print collections, the lack of a document delivery system, the establishment of new universities and the rapid increase in scientific publications. Within ANKOS, all contracts with the publishers allow members to join on agreed terms such as in CIBER and NESLI, i.e., ANKOS is an opt-in consortium. Over time, for many universities and research institutions, joining the consortium became the only option. The development of ANKOS was documented by two recent articles (Karasözen and Lindley, 2004; Erdogan and Karasözen, 2006). ANKOS is a member of ICOLC, $\underline{\text { SELL, COUNTER and SPARC. }}$

There are currently 94 state and 33 foundation or private universities in the Turkish higher education system. Within the last two years, 40 new universities have been founded. A university now exists in every city in Turkey; about $40 \%$ of the universities are concentrated in big cities like Istanbul, Ankara and Izmir. The higher education institutions had about 1.7 million students and academic staff in the academic year 2006-2007. The university population consisted of 55\% undergraduate, 31\% vocational, 9\% Master and $\mathrm{PhD}$ students, and 5\% academic staff. In all licensing negotiations, ANKOS used the number of undergraduate, graduate students and academic staff, excluding the two- or four-year colleges, as FTE numbers, which is about one million. It should be mentioned that the electronic journals were mostly used by graduate students and academic staff. Because education in most of the universities is lecture-based, the undergraduate students use the online scientific resources less than in Europe and the USA. According to the FTE numbers, Turkish universities can be classified into four categories: 15 large universities with more than 20,000 FTE's, 18 medium-sized universities with 5,000-20,000 FTE's, 27 small universities with 2,000-5,000 FTE's and 16 very small universities with less than 2,000 FTE's.

Turkey can be grouped with China, Taiwan, South Korea and Brazil as one of the most dynamic countries in terms of the increase in scientific publications (Glaenzel and Wolfgang, 2008). In 1991, there were about 1,300 publications on the Web of Science ISI database. This number increased to over 16,000 in 2007 , which corresponds to an average annual increase rate of about $14 \%$. Similarly, the ratio of research and development expenditure on gross domestic product rose from $0.32 \%$ in 1992 to $0.76 \%$ in 2006 . It should be noted that Turkey is among those countries in which most of the research was carried out in the universities. 


\section{Consortial Usage of Electronic Journals}

Since the establishment of library consortia and the growth of big deals/major contracts, several studies have appeared in recent years in which the usage of e-journals was researched with respect to their cost-effectiveness, user diversity according to research fields, and other relevant factors (see for example Karasözen, Kaygusuz, Özen(Bati), Hacer, 2007; Tonta and Ünal, 2008; Gargiulo, 2003, Bevan, Dalton and Conyers 2005, Boukacem-Zeghmouri and Schöpfel, 2008).

In 2007, the total number of full-text downloads reached about twelve million. In the first years of the consortium, the annual increase rate of full-text downloads and of participating members was about $75-80 \%$, it but slowed to $15-20 \%$ in the last few years. These figures are comparable with usage statistics in the French consortium Couperin (Boukacem-Zeghmouri and Schöpfel, 2008) and with the NESLI study (Bevan, Dalton and Conyers, 2005). In 2007, among the 86 ANKOS members, 46 institutions subscribed to 1-10 databases, 28 members to $11-20$ databases, and 12 to more than 21 databases.

In 2007, more than 50 universities had access to the major interdisciplinary e-journal collections Science Direct, Springer, Blackwell, Wiley and Taylor \& Francis. On average, 20 ANKOS members subscribed to university press and more disciplinary society e-journal packages. The sharpest increase in the number of participating members occurred for Ebrary, where the number of ANKOS members increased from 8 in 2004 to 70 in 2007. This increased demand for e-books is probably due to insufficient and scattered printed book collections in the university libraries and to inefficiencies within the inter-library loan system. Many libraries are currently experimenting with access to other e-book collections.

In Table 1, the full-text downloaded articles of COUNTER compliant e-journal collections within ANKOS are listed. Columns 2-4 give the number of subscribing institutions and the last three columns give the full-text downloads over the years. One observes an increase in usage for the majority of e-journal collections, while JSTOR, Ebsco Publishing, Blackwell Publishing, and Springer are the most dynamic with respect to increase in usage. As in many other consortia, Science Direct is in the lead with about $40 \%$ of all ANKOS full-text usage. 
Table 1. Full-text downloads within ANKOS.

\begin{tabular}{lcccrrr}
\hline e-journal packages & \multicolumn{3}{c}{ Consortium members } & \multicolumn{3}{c}{ Full-text downloads } \\
\cline { 2 - 7 } & 2005 & 2006 & 2007 & \multicolumn{1}{c}{2005} & \multicolumn{1}{c}{2006} & \multicolumn{1}{c}{2007} \\
\hline American Computing Machinery & 11 & 13 & 15 & 37,077 & 42,546 & 55,477 \\
American Chemical Society & 18 & 23 & 27 & 161,327 & 168,465 & 193,448 \\
Blackwell Publishing & 37 & 43 & 53 & 571,120 & 803,117 & 981,463 \\
Cambridge University Press & 20 & 20 & 30 & 27,258 & 45,828 & 68,362 \\
Ebsco Publishing & 44 & 52 & 56 & $1,062,730$ & 864,198 & $1,470,842$ \\
Emerald & 18 & 18 & 19 & 53,734 & 88,412 & 71,677 \\
Institute of Physics & 25 & 25 & 30 & 48,234 & 52,519 & 74,153 \\
JSTOR & 20 & 27 & 43 & 246,498 & 381,371 & 543,027 \\
Nature & & 10 & 10 & & 75,163 & 75,126 \\
Oxford University Press & 27 & 28 & 33 & 225,127 & 272,509 & 238,513 \\
Proquest 5000 & 14 & 14 & 15 & 261,833 & 232,924 & 275,201 \\
ScienceDirect & 59 & 66 & 66 & $5,232,730$ & $5,694,351$ & $5,843,049^{*}$ \\
Springer & 42 & 48 & 53 & 504,007 & 443,862 & 689,298 \\
\hline
\end{tabular}

* Estimated by Tonta, Yaşar and Ünal, Yurdagül (2008).

In order to understand the usage patterns within the consortium, it would be helpful to look at scientific progress in Turkey over the last twenty years. According to Web of Science, between 2002-2006 among the top 50 Turkish universities, 9 universities published more than 2000 articles, 17 universities between 1000-2000 articles, 24 universities less than 1000 articles The publication profile of Turkey shows that Turkey is strong in the areas of clinical medicine, biomedical sciences, agriculture, chemistry and engineering (Glaenzel, 2008). These correspond to subject areas in which the most full-text downloads occurred within Science Direct in 2006. (See Karasözen, Kaygusuz and Özen(Bati), 2007.) The distribution of full-text downloads among the consortium members correlates with the publication output in the universities: only 6 universities had more than $4 \%$ full-text downloads in Science Direct in 2006, 10 universities had between 2-4\% full-text downloads, 22 universities $1-2 \%$, and 30 of them less than $1 \%$.

The average cost of full-text downloads for the COUNTER compliant e-journal collections in Table 1 was approximately $\$ 1.7$, the cost of databases ranging from $\$ 0.5$ to $\$ 2.6$. Because of the insufficient print collections in the universities, the databases were used in a more cost-effective way than in other consortia (see for example Boukacem-Zeghmouri and Schöpfel, 2008 for the cost of usage in French universities). There was less variation among the members institutions for large interdisciplinary databases than for more disciplinebased databases. This can be explained by the diversity of research activity among the universities. In many studies dealing with the usage of e-journals, the proportion of full-text downloads from unsubscribed titles is counted as 
one of the benefits of. Because the number of subscribed printed journals was lower within ANKOS than within other consortia, full-text downloads from unsubscribed journals came to more than $50 \%$.

\section{Conclusions}

ANKOS' success and growth has occurred in a natural way, based upon a careful identification of the needs of the members, and prioritising solidarity within the consortium between small and large libraries. Also, from the very start ANKOS adopted the international principles of ICOLC and it prepared a national site license, which became the standard license for all negotiations with the publishers. The diverse and dynamic structure of the Turkish educational system and the rapid progress of research mean that the usage statistics for each database and institution should be carefully analysed. It will also form the basis of licensing negotiations with the publishers. As remarked before (Carbone, 2008), many publishers are trying to increase their profits in so-called emerging markets, such as Asia, the Near East, Brazil and Turkey, all of which are regions or countries currently experiencing growth in the field of science. Meeting the needs of their users for scientific information in a cost-effective way will be a challenge for Turkish librarians in the future.

\section{References}

Karasözen, Bülent, Kaygusuz, Ayhan and Özen (Bati), Hacer 'Patterns of E-Journal Use within the Anatolian University Library Consortium', Serials, 20(2007), p. 37-42 http:/ / serials.uksg.org/app/home/issue. asp?referrer=parent\&backto=journal,5,62;linkingpublicationresults,1:107730,1

Karasözen, Bülent and Lindley, Jean Ann, 'Impact of ANKOS: Consortium Development in Turkey', Journal of Academic Librarianship, 30(2004), p. 402-409.

Bevan, Simon, Dalton, Pete and Conyers, Angela, 'How Usage

Statistics Can Inform National Negotiations and Strategies', Serials, 18(2005), p. 116-123, http://serials.uksg.org/app/home/issue. asp?referrer=parent\&backto=journal,10,62;linkingpublicationresults,1:107730,1

Boukacem-Zeghmouri, Cherifa and Schöpfel, Joachim, 'On the Usage of E-Journals in French Universities', Serials, 21(2008), p. 121-126, http://serials.uksg.org/app/home/ issue.asp? referrer=parent\&backto=journal,1,62;linkingpublicationresults, $1: 107730,1$ 
Carbone, Pierre, ' Consortium Negotiations with Publishers - Past and Future', LIBER Quarterly, 17(2007)2, http:/ /liber.library.uu.nl/publish/articles/000202/article.pdf

Erdogan, Phyllis and Karasözen, Bülent, 'ANKOS and Its Dealings with Vendors', Journal of Library Administration, 44(2006), p. 69-84, http:/ / www.haworthpress.com/store/ArticleAbstract. asp?sid=HSDNUT4UCRGR8L3RJRUEHAEG65N051QA\&ID=81720

Gargiulo, Paola, 'Electronic Journals and Users: The CIBER Experience in Italy', Serials, 16(2003), p. 293-298. http://uksg.metapress.com/openurl.asp?genre=article \&issn $=0953-0460 \&$ volume $=16 \&$ issue $=3 \&$ spage $=293$

Glaenzel, Wolfgang, 'Turkey on the Way to the European Union? On a Scientific Power Rising Next Door', International Society for Scientometrics and Informetrics (ISSI) Newsletter, 4(2008), p. 10-17.

Karasözen, Bülent, Kaygusuz, Ayhan and Özen(Bati), Hacer 'Patterns of E-Journal Use within the Anatolian University Library Consortium', Serials, 20(2007), p. 37-42, http://serials.uksg.org/app/home/issue. asp?referrer=parent\&backto=journal,5,62;linkingpublicationresults, 1:107730,1

Karasözen, Bülent and Lindley, Jean Ann, 'Impact of ANKOS: Consortium Development in Turkey', Journal of Academic Librarianship, 30(2004), p. 402-409 doi:10.1016/j.acalib.2004.06.008

Tonta, Yaşar and Ünal, Yurdagül, 'Consortial Use of Electronic Journals in Turkish Universities', Proceedings ELPUB2008 Conference on Electronic Publishing - Toronto, Canada - June 2008, http://eprints.rclis.org/archive/00014031/

\section{Websites Referred to in the Text}

ANKOS, Anatolian University Libraries Consortium, http://www.ankos.gen.tr/ index.php?lang=english

COUNTER, Counting Online Usage of Networked Electronic Resources http:// www.projectcounter.org/

ICOLC, International Coalition of Library Consortia, http://www.library.yale. edu/consortia/

SELL, Southern European Libraries Link. http://www.heal-link.gr/SELL/

SPARC, Scholarly Publishing and Academic Resources Coalition, http:/ /www.arl.org/sparc/ 